\title{
Replik til en anmelder
}

\author{
CARSTEN BREENGAARD
}

Anders Klostergaard Petersen har i RvT 51 anmeldt min bog Paradis-sekten, og da det som bekendt ikke er rigtig god tone at reagere på en anmeldelse, og da anmelderen i øvrigt tilkendegiver, at han både har haft fornøjelse af at læse bogen og i mange henseender deler dens synspunkter, skal jeg afholde mig fra at gå ind i en nærmere faglige drøftelse af enkeltheder, hvor vi synes uenige, eller af pointer, som han synes at have læst lidt for hurtigt hen over.

Men en enkelt problemstilling kunne det måske være nyttigt at drøfte, nemlig Klostergaard Petersens spørgsmål om bogens adressat. På dette punkt, der naturligvis er mindst lige så interessant for forfatteren som for anmelderen, synes Klostergaard Petersen noget rådvild. Eller måske rettere splittet. På den ene side lufter han en længsel efter, som han siger, 'Fussnoten mit Anhang', mens han på den anden side gerne vil give læseren det indtryk, at hovedparten af bogens pointer såmænd er både velkendte og almindelig accepterede. - Det er nu, synes jeg, svært at hævde begge positioner. Efterlyser man 'Fussnoten mit Anhang', må det vel tages som udtryk for, at bogens pointer ikke er helt så almindelig accepterede og udbredte, som Klostergaard Petersen altså også hævder.

Og hermed vil jeg - og det er faktisk mit eneste anliggende her - prøve at nærme mig en besvarelse af Klostergaard Petersens spørgsmål om, hvem bogen egentlig er skrevet for.

De efter min mening klareste svar på Klostergaard Petersens spørgsmål gives i anmeldelserne i henholdsvis Gymnasieskolen og Religion, begge fagblade for gymnasiets og hf's religionslærere. Når jeg i spørgsmålet om bogens adresse finder anmeldelserne i disse blade langt vigtigere end anmeldelser i egentlige videnskabelige tidsskrifter, skyldes det, at vi her har at gøre med tidligere modtagere af de religionsvidenskabelige institutters forskning og undervisning. Der er altså tale om sådanne, der i dagligdagens praksis skal bruge de redskaber og indsigter, som universitetsuddannelserne har udstyret dem med.

Og hvordan har så disse anmeldere, der vel må antages at være blandt de bedste af fagets formidlere, modtaget Paradis-sekten? Ja, i Gymnasieskolen (4-08) kaldes bogen 
i overskriften 'En øjenåbner', og anmelderens anliggende er ikke mindst at takke for, at der gives en fremstilling af den tidlige kristendom, der ikke er fanget ind af de massive luthersk-teologiske positioner, som, oplyses det, stort set præger alt tilgængeligt undervisningsmateriale. Helt samme opfattelse kommer til udtryk i 'Religion' (marts 2008), der oven i købet slutter med at kalde bogen den 'mest fagligt inspirerende bog jeg længe har læst'. I øvrigt gælder det, at begge anmeldelser er brede præsentationer af bogens pointer, hvad der selvfølgelig ikke ville have været tilfældet, hvis alt var så kendt stof, som Klostergaard Petersen hævder.

Jeg kunne godt supplere henvisningen til disse formidler-anmeldelser med henvisning til universitære fagfolk, som jeg - der altså ikke helt er den egensindige Klods-Hans, som Klostergaard Petersen så muntert hævder - gennem årene har drøftet sagen med, inklusive de videnskabelige konsulenter for flere forlag, men jeg lægger altså en særlig vægt på brugernes synspunkter.

Og hvad er det så, vi kan lære af disse anmeldelser? Ja, i hvert fald det, at selv hvis Klostergaard Petersen skulle have ret i, at bogens pointer er almindeligt accepterede, så kan de ikke være blevet formidlet videre til fagets brugere på en måde, der har gjort synderligt indtryk på dem. Det fremgår nemlig med stor klarhed hos begge anmeldere, at de først NU er blevet opmærksomme; at de NU har fået noget at vide, som de ikke vidste før. Dette forhold burde, synes jeg, for så vidt være vigtigere for universitetslæreren Klostergaard Petersen end, hvad universitetsforskeren Klostergaard Petersen hævder selv at have vidst, inden han læste min bog! Sagt i al venlighed og med stor respekt for Klostergaard Petersens videnskabelige profil.

Jeg har, som Klostergaard Petersen for så vidt er opmærksom på, erfaringer fra et langt professionelt liv som universitets-kristendomshistoriker. Ikke desto mindre belærer han mig frimodigt om, hvilke erfaringer jeg i den sammenhæng tidligt burde have høstet og derfor lagt til grund for bogen. F.eks. at urkristendommen ligner nutidens nyreligiøse bevægelser. Til denne belæring må jeg sige, at i mit københavnske miljø har nyreligiøsitetseksperterne aldrig formået at bidrage med andet end en nedladende kristendomskritik og en anvendelse af kildematerialet som illustration for forudfattede mere eller mindre fikse ideer.

Den for mig afgørende faglige erfaring har været en stadig stigende tvivl, om de positioner, jeg selv er uddannet i, og som jeg i en årrække selv docerede, og som yderligere mødte mig som censor ved lærereksamen, ja, nærmest ligegyldigt hvor kristendomsfaglige grundsynspunkter blev berørt, nu også var udtryk for historisk læsning af kristendommens ældste tekster. Den stigende tvivl på dette har, alle andre erfaringer til trods, været min mest afgørende faglige erfaring. Netop derfor har jeg allerede i bogens indledning pointeret, at mit arbejde har været præget af kildernes modstand mod mine positioner. Og desuden at kilderne til slut havde ført mig hen et sted, hvor jeg for så vidt ikke bryder mig om at være. Bogens 'ideosynkratiske karakter', som Klostergaard Petersen dog angiveligt til slut er kommet til at skønne på, har altså i særlig grad haft adresse til mig selv og til sådanne, der har haft de samme erfaringer 
som jeg. De to nævnte anmeldelser tilkendegiver på overbevisende måde, at sådanne er temmelig mange. - Og glem nu ikke, kære kollega Klostergaard Petersen, at det faktisk var Klods-Hans, der - trods formskærerlaugets rynken på næsen - fik prinsessen og det halve kongerige.

Carsten Breengaard Dr.theol., lektor emeritus 